\title{
RESPONSES TO MORE SEVERE PUNISHMENT IN THE COURTROOM: EVIDENCE FROM TRUTH-IN-SENTENCING LAWS
}

\author{
Fusako Tsuchimoto \\ Libor Dušek
}
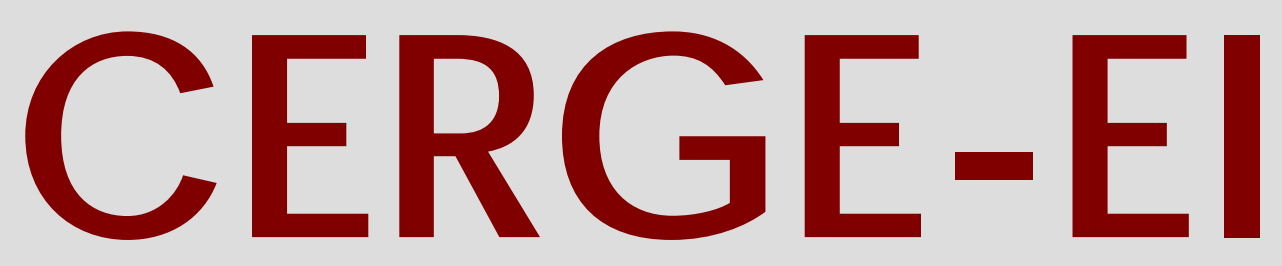

Charles University Centerfor Economic Research and Graduate Education Academy of Sciences of the Czech Republic Ec onomic s Institute 


\title{
Working Paper Series (ISSN 1211-3298)
}

\section{Responses to More Severe Punishment in the Courtroom: Evidence from Truth-in-Sentencing Laws}

\author{
Fusako Tsuchimoto \\ Libor Dušek
}

CERGE-EI

Prague, December 2009
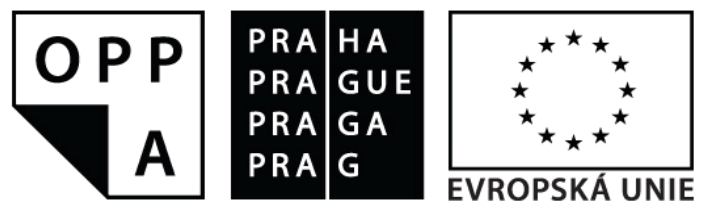

EVROPSKÝ SOCIÁLNÍ FOND

PRAHA \& EU: INVESTUJEME DO VAŠÍ BUDOUCNOSTI

Projekt je financován Evropským sociálním fondem, rozpočtem hl. města Prahy a státním rozpočtem 
ISBN 978-80-7343-205-8 (Univerzita Karlova. Centrum pro ekonomický výzkum a doktorské studium)

ISBN 978-80-7344-194-4 (Národohospodářský ústav AV ČR, v.v.i.) 


\title{
Responses to More Severe Punishment in the Courtroom: Evidence from Truth-in-Sentencing Laws
}

\author{
Fusako Tsuchimoto and Libor Dušek*
}

December 2009

\begin{abstract}
We investigate behavioral responses of judges and prosecutors to more severe punishments by analyzing the effects of Truth-in-Sentencing (TIS) laws in a large sample of individual criminal cases. The TIS laws raised effective punishment by requiring offenders to serve at least $85 \%$ of their imposed sentence in prison. Differences between the U.S. states in the timing of adoption and the types of crimes covered provide a source of identification. The key findings are: (1) The TIS laws reduced the probability that an arrested offender is eventually convicted by $25 \%$ through an increase in the probability that the case is dismissed, a reduction in the probability that the defendant pleads guilty, and a reduction in the probability that the defendant is convicted at trial. (2) The TIS laws the reduced the imposed sentence that a defendant may expect upon arrest by $14 \%$. The behavioral responses are empirically important to partially mitigate the intended deterrent effect of the TIS laws.
\end{abstract}

\begin{abstract}
Abstrakt
Článek zkoumá reakce soudců a prokurátorů na zpř́ísnění trestů odnětí svobody tím, že analyzuje dopady reforem trestního práva $\mathrm{v}$ jednotlivých státech USA, souhrnně označovaných jako zákony o „Truth-in-Sentencing" (TIS). Zákony TIS vyžadovaly, aby odsouzení zločinci byli propuštěni až po uplynutí $85 \%$ uložené trestní sazby, čímž oproti předchozí praxi výrazně prodloužily dobu, kterou zločinec stráví ve vězení. Dopady zákonů TIS odhadujeme na datovém souboru o cca 80,000 trestních př́padech ve vybraných okresech USA v letech 1990-2002. Identifikace odhadů využívá rozdílů mezi státy v roce, kdy zavedly zákony TIS, a v druzích trestných činů, na které se tyto zákony vztahovaly. Hlavními zjištěními jsou: (1) Zákony TIS snížily pravděpodobnost, že zatčený obviněný bude odsouzen, o $25 \%$. Za tímto celkovým poklesem stojí reakce subjektů v různých fázích trestního procesu -- vyšší pravděpodobnost, že trestní stíhání bude zastaveno, nižší pravděpodobnost, že obviněný přistoupí na dohodu o vině a trestu, a nižší pravděpodobnost, že obviněný bude odsouzen v hlavním líčení. (2) Zákony TIS snížily trestní sazbu, jejíž uvalení může obviněný očekávat, o $14 \%$. Tyto změny v rozhodování soudců a prokurátorů jsou empiricky významné a částečně zmírnily zamýšlený represivní účinek prrísnějších trestů.
\end{abstract}

Keywords: criminal procedure, criminal law, sentencing, Truth-in-Sentencing laws JEL Codes: K00, K41, K14

\footnotetext{
* CERGE-EI, Prague (a joint workplace of the Center for Economic Research and Graduate Education, Charles University, and the Economics Institute of the Academy of Sciences of the Czech Republic). We appreciate comments and suggestions from Stepan Jurajda, Orley Ashenfelter, Randall Filer, Radha Iyengar, Suzane Scotchmer, and Justin McCrary.
} 


\section{Introduction}

Laws that impose more severe punishments on criminals sometimes bring unexpected consequences. Their direct objective - to deter and incapacitate offenders by keeping them longer in prison - may be mitigated by behavioral responses of judges, jurors, and prosecutors who exercise certain amount of discretion at various stages of the criminal procedure. The jurors may become more reluctant to convict. The judges may opt to impose a shorter sentence within the limits given by the guidelines. Prosecutors may seek different charges or adjust their plea bargaining tactics. Understanding the character and empirical magnitude of the behavioral responses has important policy implications. To the extent that legislators can mandate longer sentences but cannot fully control the choices of prosecutors and judges, they should take the mitigating responses into account when legislating longer sentences. Such responses, if large enough, may render more severe punishments undesirable both on the grounds of efficiency (the deterrent effect is nil or even negative) as well as fairness (a small fraction of defendants are punished with a severe punishment while the majority is released).

This paper presents evidence on the mitigating responses by evaluating the effects of the so-called Truth-in-Sentencing laws on the outcomes of criminal cases. The TIS laws, adopted by many U.S. states during the 1990's, mandated that convicted offenders must serve at least $85 \%$ of the imposed prison sentence. This implied a stark increase in the fraction of the sentence typically served compared to the 1980's and early 1990's when prisoners served $48 \%$ on average, ${ }^{1}$ mostly due to prison overcrowding and discretionary early releases by parole officers. If the probability of conviction and the imposed sentences did not change after

\footnotetext{
${ }^{1}$ Ditton and Wilson (1999).
} 
introducing the TIS laws, an offender could spend $70 \%$ more time in prison than previously expected.

The TIS laws were part of a broader trend at the federal and state levels during the 1980's and the 1990's to reduce the discretion of judges and parole boards in determining the length of sentence served in prison and to punish certain types of offenders, namely repeat violent offenders, more severely. Since the mid 1980's the federal law required offenders convicted of federal crimes to serve $85 \%$ of their sentence. ${ }^{2}$ The Violent Crime Control and Law Enforcement Act of $1994^{3}$ encouraged the states to adopt similar provisions at the state level by introducing the so-called Violent Offenders Incarceration and Truth-in-Sentencing Incentive Grant Program. It provided grants to expand prison and jail capacity to the states that met certain criteria. To be eligible for the TIS grant, a state had to implement a TIS law that requires persons convicted of a Part I violent crime $^{4}$ to serve no less than $85 \%$ of the sentence imposed, or the state had to have a similar law that results in persons convicted of a Part I violent crime serving on average no less than $85 \%$ of the sentence imposed. ${ }^{5}$

The timing of adoption of the TIS laws by individual states varied (see Table 1). While only two states (plus the District of Columbia) had TIS-type provisions in the early 1990's, eleven other states adopted the TIS laws within one year of the passage of the Violent Crime Control and Law Enforcement Act of 1994. Twenty-seven states and the District of Columbia met the eligibility criteria by $1998 .{ }^{6}$ The states also varied in the scope of coverage of the TIS laws; the $85 \%$ requirement applied to Part I violent felonies in all adopting states, but

\footnotetext{
${ }^{2}$ U.S. Department of Justice (1993).

${ }^{3}$ Public Law 103-322, Sept. 13, 1994 (the "1994 Crime Act").

${ }^{4}$ Part I violent crime includes murder, rape, robbery, and assault.

${ }^{5}$ For more detail of criteria, see U.S. Department of Justice (2005).

${ }^{6}$ These states received $\$ 2.7$ billion in total during 1996-2001 through the VOI/TIS grant program (U.S. Department of Justice (2005)).
} 
in some states it applied to other crimes as well.

The variation among the states in the timing of adoption and the types of crimes covered is exploited to to identify the effects of the TIS laws on case outcomes. We employ two variants of a difference-in-differences-in-differences estimator to address the concern that other "tough-on-crime" policies may be correlated with the adoption of the TIS laws, or that the distribution of unobservable characteristics of cases may have changed in response to the TIS laws. The first one is based on comparing, within the adopting states, the outcomes for offense types covered and not covered by the TIS, after differencing beween the pre- and post-adoption periods and adopting and non-adopting states. This way we control for the unobservables that were correlated with the adoption of the TIS laws but were common to all crimes within a state. The second one is based on comparing, within the adopting states, outcomes between those states that imposed the TIS laws on violent as well as other crimes and those that imposed them on violent crimes only, after differencing beween the pre- and post-adoption periods and adopting and non-adopting states. This way we control for the unobservables that were correlated with the adoption of the TIS laws but affected violent crimes differently than non-violent crimes. The data used is the State Court Processing Statistics (SCPS) which consists of a large sample of felony cases from the most populous counties of the United States and allows controlling for many observable characteristics of each case.

Our most important findings come from esimating two summary measures of the causal effects of the TIS laws. The first one is the change in the probability that an arrested offender is eventually convicted, irrespective of whether by pleading guilty or at trial. It fell by $25 \%$. This result is one of the first empirical tests of Andreoni's (1991) proposition that more 
severe punishment leads to a lower probability of conviction.

The second measure is the change in the imposed sentence that an arrested offender receives at the final disposition of the case, which can also be interpreted as a change in the sentence that an offender may expect, conditional on arrest. It gives a particularly useful summary of the mitigating responses as the changes in the probability of dismissal, guilty plea, conviction at trial, and the sentence imposed upon conviction translate into the sentence that is eventually imposed. The TIS law reduced the imposed sentence conditional on arrest by $14 \%$ according to our most preferred specifications.

We provide tentative evidence on the particular channels behind the two main findings. The TIS laws reduced the probability of conviction through a higher probability that the case is dismissed as well as through a lower probability of conviction at trial. ${ }^{7}$ They also reduced the probability that the defendant would plea guilty by $25 \%$, further contributing to the reduction in the overall probability of conviction since the defendants who would have pleaded guitly were then convicted at trial with probability less than one. Pleading guilty apparently became a less favorable alternative to trial. We provide at least one piece of evidence suggesting that this was due to the behavioral response of the prosecutors rather than defendants, namely that the TIS laws reduced the likelihood that the prosecutor would reduce the charges from felony to misdemeanor by $14 \%$. In other words, the prosecutors apparently "exploited" the TIS laws to present defendants with less advantageous bargains, while we don't have alternative evidence suggesting that the defendants became less willing to accept bargains with otherwise equal terms.

At the sentencing stage, we test the hypothesis that the judges offset the higher fraction

\footnotetext{
${ }^{7}$ The last effect is significant only in the states that had adopted sentencing guidelines.
} 
of the sentence served by imposing shorter maximum sentences but, somewhat surprisingly, find little support for it.

Overall, the behavioral responses to the TIS laws mitigated their intended effect to impose more severe punishment. While the requirement to serve $85 \%$ of the sentence increased the time served in prison by $70 \%$ on average for those who received a given sentence, the reduction in the imposed sentence upon arrest by $14 \%$ implies that arrested defendants experienced an increase in the expected time served not by $70 \%$ but only by $56 \%$. Therefore, the unintended behavioral responses removed about one-fifth of the direct increase in the severity of punishment that the designers of the TIS laws intended. Our results demonstrate that the mitigating responses are actually empirically relevant and should be taken into account in the design of sentencing policies.

\section{Relation to previous literature}

This section discusses the behavioral responses to the TIS laws predicted by the theory and the existing empirical evidence. Two simple expressions organize our thinking about measurable case outcomes:

$$
\begin{aligned}
S & =s f \\
p s f & =E[s \mid A] f=E[S \mid A]
\end{aligned}
$$

The deterrent and incapacitative effects of punishment are determined in part by the sentence actually served in prison $S$ which in turn is a product of the sentence imposed 
upon conviction, $s$, and the fraction of the sentence actually served, $f$. Assuming that $f$ is deterministic, only $S$ should affect deterrence as the offender is indifferent between a 1year sentence which he fully serves in prison and a 2-year sentence of which he only serves $50 \%$. The other variable affecting deterrence is $p$, the probability that an arrested offender is convicted. The product of $p$ and $s$ is the expected sentence conditional on arrest, $E[s \mid A]$. It can be thought of as a summary measure of "output" of the criminal procedure since it has the interpretation of the sentence that is imposed on an arrested offender on average. Finally, multiplying $E[s \mid A]$ by $f$ gives the expected sentence served in prison conditional on arrest, $E[S \mid A]$. It can be thought of as the summary measure of the actual severity of punishment on average, conditional on arrest, as it combines the probability of conviction, the sentence imposed, and the fraction of the sentence actually served.

Truth-in-Sentencing laws exogenously shifted the fraction $f$ upwards by a certain percentage, and if $p$ and $s$ did not change, they would mechanically increase the sentence actually served $S$ and the expected sentence served $E[S \mid A]$ by that same percentage. However, $p$ and $s$ are determined endogenously by the actions of the agents in the criminal process and the sentence served in prison may increase by less than the mechanical change. The focus of our paper is to estimate how they respond to a change in $f$, that is, to estimate the effect on the probability of conviction $d p / d f$, the effect on the expected sentence imposed conditional on arrest $d E[s \mid A] / d f$, and the sentence conditional on conviction $d s / d f$. What we unfortunately cannot estimate is the effect on the expected sentence actually served $E[S \mid A]$ since the data on prison releases does not provide enough information on the actual practice of releasing prisoners sentenced under the TIS laws.

Our discussion of the theoretical predictions proceeds backwards from the sentencing 
stage. The judges may offset a higher fraction of the sentence actually served in prison simply by imposing shorter maximum sentences. For example, a judge might have sentenced a particular offender to 8 years in prison prior to the TIS laws, expecting that only 4 years would be served. Knowing that at least $85 \%$ of the sentence would be served after the TIS law, the judge may regard the resulting sentence actually served of 6.8 year as unjust and opt for a shorter sentence. In the extreme case, she might sentence an otherwise identical offender to only 4.7-years in prison in order to have him serve the same length of time, namely 4 years. Such a response requires judges to take into account the fact that offenders generally do not serve the full length of the maximum sentence, and to have at least some discretion in the choice of the sentence. For the last reason we expect the TIS laws to have a weaker effect in the states with sentencing guidelines where the judges's discretion is more restricted. Even though the legal literature has been concerned with the sentencing implications of parole releases (see Genego et al (1975) for an early example), the empirical evidence on the relationship between sentences imposed by judges and the anticipation that the offender will be released early is, to our best knowledge, missing.

The second behavioral response operates through the probability of conviction. Longer sentences increase the social cost of convicting an innocent defendant. The judge or jury who cares about the social costs of wrongful conviction then requires a higher standard of proof to convict a defendant (Andreoni 1991, Ezra and Wickelgren 2005). The TIS laws should therefore reduce the conviction rate among the cases resolved at trial. They should also increase the fraction of cases dismissed in the pre-trial stage if the judges require a higher standard of proof for letting the case proceed or if prosecutors, taking into account the higher standard of proof in the trial, decide to drop the cases with the weakest evidence. While 
Andreoni's original hypothesis is widely accepted as theory, empirical evidence has been scant at best. We identified only two empirical studies using real-world data. Snyder (1990) does find a reduction in the probability of conviction in antitrust cases as the level of charges for certain antitrust violations was raised from misdemeanor to felony. Bjerk (2005), who explores primarily the response of prosecutors to the three-strikes laws, also tests whether offenders qualifying for a third-strike offense face lower probability of conviction at trial, but does not find any significant effect. ${ }^{8}$

In the plea bargaining process, the change in outcomes is a combination of behavioral responses of the prosecutor (the terms of the plea bargain he offers) and the defendant (willingness to accept the terms). Formal economic models of the prosecutor's behavior assume that the prosecutor maximizes "output" measured as the sum of expected sentences or the rate of winning in trial cases (Landes 1971, Easterbrook 1983) or a more broadly defined social welfare function (Reinganum 1988, 2000). In these models the prosecutor typically offers a sentence that makes the defendant indifferent between accepting the plea or going to trial. ${ }^{9}$ As the TIS laws increased the sentence actually served in prison $S$ for the defendants convicted at trial, the models unambiguously predict that the sentence actually served in prison offered by the prosecutor also rises. In a sense the prosecutor "exploits" the fact that the defendant is willing to accept a longer sentence actually served in plea

\footnotetext{
${ }^{8}$ Bjerk's result may plausibly be explained by sample selection. The three strikes laws made it more likely that a felony defendant with two prior strikes would have charges reduced to a misdemeanor (resulting in cases with relatively stronger evidence being prosecuted as felonies) and that he would not accept the plea bargain (resulting in cases with relatively stronger evidence being continued to trial). The shift in the distribution of cases reaching trial shifts the probability of conviction upward, offsetting the predicted behavioral response.

${ }^{9}$ If the offenders are of different types (e.g., when they have imperfect information about the strength of evidence against them) and the prosecutor cannot distinguish their type, the optimal sentence offered involves only a marginal defendant being indifferent between the plea and trial, while defendants who think the case against them is weak strictly prefer a trial while those who think the case against them is strong strictly prefer pleading guilty.
} 
bargaining if the trial sentence rises.

Whether the TIS laws would lead to longer or shorter imposed sentences $s$ in plea bargaining is theoretically ambiguous. The TIS laws applied to offenders convicted of certain charges irrespective of whether they were convicted at trial or pleaded guilty. For an offender who would be convicted of exactly the same charges, the TIS laws have increased the sentence actually served $s f$ by the same percentage for both trial and plea convictions. The prosecutor need not adjust the imposed sentence $s$ to increase the sentence actually served $S$ that he offers. Whether he would optimally adjust the offered sentence upward or downward depends on the details of the model. ${ }^{10}$ However, pleading guilty often times implies being convicted of different charges compared to a potential conviction at trial (a misdemeanor instead of a felony, a less serious offense, some charges being dropped if arrested for multiple charges). In such cases $f$ increases only if the defendant is convicted at trial, and the gap between the trial sentence and the plea sentence widens. A maximizing prosecutor should then optimally respond by offering a tougher bargain by proposing a longer sentence $s$ or by being less willing to reduce the level of charges.

Several empirical papers support the prediction that prosecutors "exploit" enhanced statutory sentences. Kuziemko (2006) shows that defendants in murder cases in New York were accepting plea bargains with harsher terms after the state reintroduced the death penalty in 1995, while the likelihood that the defendant would plead guilty did not change. Kessler and Piehl (1998) find that California's Proposition 8, a popular initiative that mandated enhanced sentences for offenders with certain criminal histories who committed crimes subject to Proposition 8 caused an increase in sentences for those crimes as well as for crimes

\footnotetext{
${ }^{10}$ For example, the very basic version of the Landes (1971) model with risk-neutral defendants and positive costs of a trial predicts that the prosecutor should reduce the maximum sentence offered.
} 
that were factually similar but were not subject to Proposition 8 .

A different line of literature offers a different view on the prosecutors' objectives and yields different predictions. The objective of the prosecutors is to "further justice" and apply social norms of what constitutes an appropriate punishment. If they regard a legislated increase in the severity of punishment as unjust, they would use their discretion to mitigate some of its effects. In the context of the TIS laws, they would propose shorter sentences or would be more likely to reduce charges. Bjerk (2005) provides empirical support. He studies the impact of the three-strikes laws which dramatically enhanced prison sentences to criminals with at least two prior violent felony convictions. The prosecutors became more likely to reduce the charge from felony to misdemeanor when the defendant was at risk of receiving a three-strike sentence. In a similar vein, Walsh (2004) documents that between $25-45 \%$ of offenders eligible for a three-strike sentence in urban counties in California have their prior strikes dismissed. ${ }^{11}$ Shepherd (2007) shows that crime rates have risen after the adoption of sentencing guidelines during the 1980's and the 1990's in the U.S. states that adopted them relative to the states that did not. While surprising, the finding is consistent with the prosecutors and judges being less willing to prosecute or convict offenders for crimes for which the guidelines prescribe sentences that are deemed unduly harsh. ${ }^{12}$

\footnotetext{
${ }^{11}$ The findings by Bjerk (2005) and Walsh (2004) can alternatively be rationalized as an optimal response by prosecutors who maximize the average sentence or number of convictions at trial subject to the resource constraint. Realizing that the judge or jury will be very reluctant to convict a defendant with two prior strikes when the punishment for the third-strike offense is deemed too severe (typically a situation when the third strike is a relatively petty crime), the prosecutor anticipates that winning the case would require substantial resources that would no longer be available for other cases. Offering "softer" terms to the defendant is then optimal even for a prosecutor who maximizes the average sentence and need not necessarily indicate an intentional objective to mitigate very long sentences.

${ }^{12}$ Unfortunately the empirical strategy does not distinguish whether the impact of the guidelines on crime was due to the offsetting responses or through channels that affect deterrence directly. Reduced disparity in sentences implies that the most serious offenders may face shorter sentences than they would have received without the guidelines, and it could make the expected punishment less costly in expected utility terms for risk averse offenders.
} 
The predicted impact of the TIS laws on the defendants' plea choice is ambiguous. In the absence of behavioral responses by the prosecutor or the judge or jury, they would be more likely to plead guilty if the TIS law applies only to the trial sentence. However, if the prosecutors offer tougher bargains because of the TIS laws, the plea rate may fall. Likewise, if the probability of conviction at trial decreases and the offenders are aware of it, they would also be less willing to accept the plea. The sign of the change in the plea rate is ultimately an empirical matter. A smaller fraction of cases where the prosecutors reduce charges and a smaller fraction of cases settled through plea bargaining would be consistent with the "prosecutorial maximization" view. The opposite effects would be consistent with the "furtherance of justice" view of the prosecutors.

The overall probability $p$ that an arrested offender is convicted (by pleading guilty or at trial) is expected to fall, although there is a theoretical possibility that it would rise if the defendants become sufficiently more likely to accept plea bargains. The other summary measure, the expected imposed sentence conditional on arrest $E[s \mid A]$ is expected to decrease as well since both the probability of conviction as well as the sentence upon conviction are expected to decrease.

Our paper improves upon the empirical research on behavioral responses to longer sentences in several ways. Most importantly, we estimate two simple summary measures of the behavioral responses across all stages of the criminal procedure, namely the changes in the probability of conviction and the imposed sentence, both conditional on arrest. Second, we also investigate the responses in all stages of the criminal procedure. Third, we use a caselevel dataset that covers a large set of crimes and allows controlling for many characteristics of cases and defendants, the distribution of which may have been affected by the change in 
the TIS laws as well.

Last, the paper exploits a new policy context to estimate the behavioral responses, and as such it provides several policy-relevant findings about the effects of the TIS laws themselves. So far, Shepherd (2002) analyzed their deterrence effects. Using a county-level panel, she estimates the effect of the TIS laws on crime rates, arrest rates, and the median prison sentences. She finds that the arrest rates increased with the introduction of TIS laws as the states that introduced the TIS laws tended to adopt a "tough on crime" attitude and the police made more effort to arrest. Similarly she finds an increase in the imposed prison sentences. Her estimates can be interpreted as evidence of judges and prosecutors not offsetting the enhanced effective sentences by imposing shorter sentences or offering better plea bargains; alternatively they can be interpreted as evidence of other "tough on crime" policies that were correlated with the adoption of the TIS laws. Our empirical strategy differs from that of Shepherd; we use case-level as opposed to county-level data and our "difference-indifferences-in-differences" estimator allows controlling for the unobservable "tough on crime" policies. Still, our results generally concur with those of Shepherd. Specifically, we also find a reduction in the plea rate and an overall increase in the sentences imposed on those convicted. In addition, we provide new findings of a substantial reduction in the probability of conviction and an overall reduction in the sentence imposed conditional on arrest. 


\section{Data and empirical strategy}

We use the "State Court Processing Statistics: Felony Defendants in Large Urban counties," an individual level dataset on approximately 100,000 criminal cases in state courts. ${ }^{13}$ The sample covers 45 counties selected from $75 \%$ of the most populous counties in the United States. It tracks cases that were filed in May of every even year from 1990 till 2002. The universe of the dataset is cases initiated by a felony arrest. ${ }^{14}$ Due to missing values for relevant variables in some observations, the sample used in regressions has over 83,000 observations.

The SCPS data set contains rich information on each case: offender characteristics such as age, sex, and detailed prior record, information about the procedural aspects of the case (pretrial detention, type of attorney), and the final disposition of the cases including the length of the maximum jail or prison sentence, if applicable. The offense types that appear in the data set are part I violent crime (Murder, Rape, Robbery, Assault) and other crime (Burglary, Larceny-Theft, Motor Vehicle Theft, Forgery, Fraud, Drug Sales).

Table 2 summarizes the data for the states that eventually implemented the TIS laws, dividing the sample into violent and non-violent crimes and into observations before and after the TIS law was implemented. The raw data do not indicate significant changes in the outcome variables for violent crimes, one exception being the sentence in trial cases which increased from 101 to 133 months. For non-violent crimes the summary statistics show an increase in the fraction of cases dismissed or acquitted (from 20 to 29\%), reduction in the fraction of pleas (from 70 to $63 \%$ ) and a large reduction in the average sentence at trial (from 35 to 16 months).

\footnotetext{
${ }^{13}$ The data is collected by the Bureau of Justice Statistics. ICPSR study \#2038.

${ }^{14}$ About $15 \%$ of cases end up adjudicated as misdemeanors.
} 
The empirical strategy is based on a "quasi natural experiment" which compares the treatment cases (those covered by the TIS laws) with appropriately chosen control cases. We adopt two alternative "difference-in-differences-in-differences" estimators, formally stated as

$$
\begin{aligned}
& Y_{i c s t}=f\left(\text { TIS }_{\text {icst }}, \text { TIS State }_{s t}, X_{i c s t}, \lambda_{c}, \lambda_{t}, \lambda_{\text {av }}, \epsilon_{i c s t}\right) \\
& Y_{i c s t}=f\left(T I S_{i c s t}, \text { TISstate } \times \text { violent }_{c s t}, X_{i c s t}, \lambda_{c}, \lambda_{t}, \lambda_{\text {av }}, \epsilon_{i c s t}\right),
\end{aligned}
$$

where $i, c, s$, and $t$ denote the individual case, offense type, state, and year, respectively. $Y_{i c s t}$ stands for the outcome variable and $T I S_{i c s t}$ is a dummy variable indicating whether the individual case is covered by the TIS law. ${ }^{15}$ TISstate $_{s t}$ is a dummy variable equal to one if a state has the TIS law in force. TISstate $\times$ violent $_{c s t}$ is a dummy variable equal to one if a state has adopted the TIS laws and a given offense is a violent felony. $X_{i}$ is a vector of individual characteristics of the offender and the case. ${ }^{16}$ Finally, we include offense and year fixed effects $\lambda_{c}$ and $\lambda_{t}$, and county-violent crime fixed effects $\lambda_{a v} \cdot{ }^{17}$ The county-violent crime fixed effects control for unobserved heterogeneity in violent and non-violent crimes at the county level, which would arise if, for example, county A has a higher proportion of violent crimes that are drug-related than county B, and drug-related violent crimes have on average

\footnotetext{
${ }^{15}$ The TIS case dummy may change for a given case during the criminal process. For example, the person may be arrested for a violent felony, and if convicted for a violent felony, the TIS law would apply. However, he may be convicted for a misdemeanor, and the TIS law would no longer apply. In the regressions we set the TIS law according to the offense type that the offender is charged with at the relevant stage of the criminal process.

${ }^{16}$ Prior felony convictions (measured by dummies for 1,2 , and 3 or more prior convictions), number of prior misdemeanor convictions, log age, log age interacted with the prior conviction dummies, gender dummy, race/origin dummies (white non-hispanic, black non-hispanic, hispanic, and other), and type of attorney (public, private, assigned, pro se, and other) are included in the $X$ vector.

${ }^{17}$ Represented by interactions of county dummies with a dummy variable equal to one for violent offense and zero for other offenses.
} 
different outcomes in the criminal process than other violent crimes. ${ }^{18} \epsilon_{i c s t}$ is an error term.

We use the difference-in-differences-in-differences, as opposed to the more conventional difference-in-differences estimator since the identifying assumption for the latter is unlikely to hold. It would require that there was no differential change between the adopting and non-adopting states in the unobservables that affect outcomes in the offenses covered by the TIS laws after the adopting states implemented them. However, the states adopted the TIS laws, among other reasons, because they wanted to punish certain crimes more severely or to convict more defendants, and therefore they may have implemented other "tough on crime" policies. ${ }^{19}$ Also, the unobservable characteristics of the criminal cases, as recorded in our data at the time of felony arrest, may have changed either due to a change in policing intensity or the underlying crime in response to the TIS laws (Shepherd 2002). For either reason, the error term would be correlated with the $T I S_{i c s t}$ case dummy variable.

Our first specification (equation 3) therefore includes a TIS state control (variable TISstate st $_{\text {). }}$ It captures the effect of state-specific unobservable variables that are potentially correlated with the adoption of the TIS laws and affect all crimes equally. The effect of the TIS laws is estimated from a within-state comparison of the change in the outcome for the crimes covered by the TIS laws with the crimes that are not covered. It is identified under the assumption that within a state there is no differential change in the distribution of unobservable case characteristics between the TIS offenses and other offenses, even though there

\footnotetext{
${ }^{18}$ Ideally, we would include the county-offense fixed effects. However, there are too few observations for many county-offense combinations which prevents a meaningful estimation. The county-violent crime fixed effects are therefore a workable compromise, still superior to a specification with only county or state fixed effects which assumes away any differences in unobserved heterogeneity between offense types within a state.

${ }^{19}$ One example is the VOI grants introduced with the same federal legislation as the TIS laws. States were eligible for addtional (the so-called VOI) grants if they satisfied additional criteria, such as demonstrating that the severity of punishment for part I violent offenders has increased since 1993. Another example is the sentencing guidelines, the adoption of which may have been actually encouraged by the introduction of the TIS laws (Dharmaphalla, Garoupa, and Shepherd 2006).
} 
may be a differential change between adopting and non-adopting states. In other words, the adopting states may have gotten "tougher on crime" than the non-adopting states, but then did so equally for all crimes.

The second specification (equation 4) exploits the fact that violent felonies are covered by the TIS laws in all states that adopted them while property, drug, and other non-violent crimes are covered only in some states. It hence includes a TIS state-violent crime interaction (variable TISstate $\times$ violent $_{c s t}$,) which captures the effect of unobservables that are correlated with the adoption of the TIS laws and affect violent crimes only. The effect of the TIS laws is estimated from a between-state comparison of the change in outcome for non-violent crimes in the states that imposed the TIS requirement on both violent and non-violent crimes with the states that imposed the TIS laws on violent crimes only. The estimates are identified under the assumption that there is no differential change in the distribution of unobservable case characteristics in non-violent cases between these two groups of adopting states. In other words, the adopting states may have gotten "tougher" on violent than on non-violent crimes but must have gotten proportionately tougher on violent crimes irrespective of whether they imposed the TIS laws on all crimes or just violent crimes.

Admittedly, the estimates are not identified if states imposed the TIS laws on certain crimes and at the same time targeted other "tough on crime" policies on the same crimes. Then the effects of the TIS laws cannot be separated from the effects of those other policies or changes in the distribution of unobservable case characteristics. ${ }^{20}$

The last empirical issue concerns the sample selection. As the cases proceed through several steps of the criminal procedure, the remaining subsample of cases becomes gradually

\footnotetext{
${ }^{20}$ Unfortunately, there is no case-level variation within a particular crime (which would be the case if the TIS laws applied only to offenders with certain characteristics, for example).
} 
more selected. If the TIS laws change the distribution of unobservable characteristics of cases that proceed to the next stage, the estimates made on subsamples of subsequent cases are potentially biased by changes in sample selection. For example, if the TIS laws reduce the fraction of cases settled in plea bargaining, the marginal offenders now proceding to trial would face a longer potential sentence than the average offender previously proceding to trial. This change in the composition would bias the estimate of the effect of the TIS laws on the sentence in trial cases upwards.

Fortunately, the estimates of our key summary measures of the impact of the TIS laws are not affected by sample selection. Both the probability of conviction conditional on arrest and the expected sentence imposed conditional on arrest are estimated on a full sample of arrests, where no cases have yet been selected for the subsequent stages. The same is true when we investigate some of the channels behind the summary measures, namely the probability that an arrested defendant is convicted through plea bargaining and the probability that the case is dismissed. For other channels, namely the probability of conviction at trial and the sentence conditional on conviction, the estimates are potentially contaminated by the sample selection and therefore should be interpreted with caution. Unfortunately we do not have instruments that would be correlated with the likelihood that the case proceeds to the subsequent stage and at the same time would not be correlated with the error term in the outcome equation in that stage. We still think it is preferable to present these results as tentative evidence while acknowledging their shortcomings. 


\section{Results}

\subsection{Probability of conviction conditional on arrest}

The first set of regressions estimates our first summary measure of the impact of the TIS laws: the change in the probability that an arrested offender is eventually convicted, irrespective of whether via plea bargaining or conviction at trial. Table 3 presents the probit estimates. The coefficients on the TIS case dummy variable show that TIS laws resulted in a large drop in the likelihood of conviction on the order of $25 \%$. This result is robust to alternative specifications - controlling for the TIS state or the TIS state-violent crime interaction (columns 1 and 2) and further including the dummy variables for whether the state has sentencing guidelines and the interaction of the sentencing guidelines and TIS case dummies (columns 4 and 5).

We also report the coefficients on the TIS state control and the TIS state-violent crime interaction to demonstrate the appropriatness of the diff-in-diff estimator. The coefficients on both of these control variables are on the order of $0.1-0.115$, indicating that by itself, the introduction of the TIS laws was associated with a 10-15\% overall increase in the probability of conviction across all cases, even those that were not subject to the TIS laws. ${ }^{21}$

We also estimate the impact of the TIS laws specific to individual crime categories: murder, violent crime (other than murder), property, and "drug and other" crime. ${ }^{22}$ The estimates (columns 3 and 6) show significant reductions in the probability of conviction

\footnotetext{
${ }^{21}$ Correspondingly, our estimates are different from the simple diff-in-diff estimates. When we exclude the TIS state $_{s t}$ or the TISstate $\times$ violent $_{c s t}$ variables from the regression to estimate the diff-in-diff, the coefficient on the TIS $S_{i c s t}$ dummy rises to -0.18 .

${ }^{22}$ The "violent crime" category includes rape, robbery, assault, and other violent crime; "property crime" category includes burglary, larceny-theft, motor vehicle theft, forgery, fraud, and other property crime; "drug and other crime" category includes drug sales, other drug offenses, weapons-related offenses, driving-related offenses, and other offenses. The drug-related offenses are by far the most prevalent in the last category $(79 \%)$
} 
across all crime categories except murder and they are more pronounced for the relatively minor crimes (property and drug/other), indicating reductions by $44 \%$ and $35 \%$ respectively (column 6). ${ }^{23}$ Even though these regressions do not directly estimate the choices by judges and juries at trial, they nevertheless provide strong support for Andreoni's prediction in the sense that the criminal justice "system" convicts less if the sentences are raised.

\subsection{Imposed sentence conditional on arrest}

The second summary measure of the behavioral responses to the TIS laws is the change in the sentence imposed conditional on arrest. It is obtained by estimating equations 3 and 4 on the full sample of arrests, the dependent variable being the logarithm of the maximum prison or jail sentence imposed (in months). If the defendant was not convicted, the sentence in the regressions is set to zero. ${ }^{24}$ The TIS laws would have no effect on the imposed sentence in the absence of any behavioral response. A negative coefficient on the TIS case dummy indicates that the behavioral responses led to a reduction in the imposed sentence on average - either through a change in the probability of conviction or a change in the length of sentence conditional on conviction, or a combination of the two effects.

We estimate Tobit and quantile regressions instead of the conventional OLS for two reasons. One, the observed sentences are censored at zero. Second, we expect the TIS laws to have a weak (or nil) impact in cases where the sentence is very short, since the difference between serving, say 5 weeks or 8.5 weeks out of a 10 -week maximum sentence may not be of such a concern to the judge than the difference between serving, say 5 years or 8.5

\footnotetext{
${ }^{23}$ It is impossible to estimate the specification with the TISstate $\times$ violent interaction variable because all states that adopted the TIS laws covered all violent crimes. The effects on violent crimes overall and sub-categories of violent crimes cannot be separated.

${ }^{24}$ To deal with the logarithm of zero, we add one month to each sentence.
} 
years out of a 10-year maximum sentence. A similar argument likely applies to extremely long sentences for murders where the requirement to serve $85 \%$ out of a 70 -year maximum sentence may be of little practical significance. We therefore run two sets of Tobit regressions with the upper bound on the imposed sentence set at 65 years and the lower bound set at either 4.5 months or zero.

The quantile regression predicts a change in a given quantile of the distribution of the dependant variable (conditional on $X$ ) due to a change in the independent variable. We expect the TIS laws to have a stronger effect in the higher quantiles of the distribution of the sentence which we capture by estimating the model at several quantiles.

Table 4 shows the Tobit estimates. In the specifications with the TIS state control, the coefficient on the TIS case dummy is -0.148 when the lower bound is zero (column 1) and -0.099 (column 4) when the lower bound is 4.5 months, and they are significant at $5 \%$. In the specification controlling for the TIS state-violent crime interaction the coefficients are larger in magnitude $(-0.215$ and -0.144 for the respective lower bounds, columns 2 and 5$)$ and significant at $1 \% .^{25}$

Columns 3 and 6 report crime-specific estimates. The offsetting response to the TIS laws appears to have occurred only for property and drug/other crime. The estimates imply a reduction in the expected imposed sentence for property crime by 32 percent (specification with a lower bound at zero) 20 percent (lower bound at 4.5 months). The corresponding estimates for the drug/other crimes imply a 27 or 19 percent reduction. ${ }^{26}$

\footnotetext{
${ }^{25}$ The coefficients on the TIS state and TIS state-violent crime interaction controls are positive as expected and significant at $1 \%$ level. The unobserved factors that they capture increased the expected sentence by approximately $12 \%$ for average crime and $22 \%$ for violent crimes (columns 4 and 5 ).

${ }^{26}$ The estimated crime-specific effects are small and insignificant for violent crime and actually positive and large (0.51) for murder.
} 
The estimates of the quantile regressions for the 75th and 90th quantiles are shown in Table 5. ${ }^{27}$ They demonstrate that the behavioral response leading to shorter expected sentences was concentrated on the longest expected sentences, conditional on other factors. The coefficients on the TIS case dummy are insignificant (in the specification with the TIS state control) or even positive (in the specification with the TIS state-violent crime interaction) in the 75th quantile regressions (columns 1 and 3), but they have the expected negative sign and are statistically significant in the 90th quantile regression. Their magnitude $(-0.288$ in the specification with the TIS state control and -0.189 in the specification with the TIS state-violent crime interaction) is larger than the corresponding Tobit estimates.

Both sets of regressions show fairly consistently that offenders covered by the TIS laws experienced a reduction in the sentence that they may expect at the time of arrest, compared to other cases. The reduction was not trivial; we regard $14 \%$ suggested by two of the Tobit estimates as the most preferred, and rather conservative, result.

\subsection{Probability of conviction disentangled}

After presenting the summary measures of behavioral responses, we proceed by investigating the specific channels leading to the reduction in the overall probability of conviction and the expected imposed sentence.

The TIS laws may have reduced the likelihood of eventual conviction through three channels: a higher probability that the case is dismissed before reaching a verdict on merits, a lower probability of conviction at trial, or a lower probability that the offender accepts a

\footnotetext{
${ }^{27}$ The quantile regressions are estimated at 75 th and 90 th percentiles only. They could not be estimated at lower quantiles since zero sentence represents most observations for the 50th or lower quantile for most $X^{\prime} s$, leaving almost no variation in the dependant variable.
} 
plea bargain. Table 6 estimates the magnitude of the first channel by a probit regression with a dependant variable equal to one if the case was dismissed. The marginal effects of the TIS case dummy are 0.154 and 0.10 in the two basic specifications, and both are significant at the $1 \%$ level. $^{28}$ The tendency to convict less apparently applies to other stages of adjudication and not just to conviction/acquittal verdicts at trial. Unfortunately we cannot say to what extent the higher probability of a dismissal is due to more dismissals by the judges during the pre-trial reviews and preliminary hearings or by the prosecutors since both are theoretically plausible.

The effect of the TIS laws on the probability of conviction at trial is estimated in Table 7. The results show a large $(-25 \%)$ and barely significant reduction in the specifications without sentencing guidelines variables (columns 1-3). When we control for the presence of the sentencing guidelines in the state, the TIS dummy is no longer statistically significant but its interaction with the sentencing guidelines is, implying that the TIS cases have a $50 \%$ lower probability of conviction at trial in the guidelines states. ${ }^{29}$

\subsection{Plea bargaining}

The next set of probit regressions estimates the effect of the TIS laws on the likelihood that the case outcome is a guilty plea (Table 8 ). The estimates show a $25 \%$ reduction in the the specification with the the TIS state control (column 1) and a $28 \%$ reduction in the specification with the TIS state-violent crime interaction.

\footnotetext{
${ }^{28}$ The coefficients on the TIS state and TIS state - violent crime interaction controls are negative, again indicating a presence of other "tough on crime" policies that tended to reduce dismissals.

${ }^{29}$ The results have to be interpreted with caution since the trial cases represent a highly selected sample. If the TIS laws induce more dismissals of the weakest cases, than the subsample of trial cases is made of relatively stronger cases, which induces a higher probability of conviction.
} 
The reduction in guilty pleas did not come about mechanically from the fact that more cases were dismissed and therefore fewer cases were left to be potentially resolved through plea bargaining. When regressions in Table 8 are re-estimated on a subsample of cases that were resolved either through plea bargaining or at trial, the coefficients on the TIS case dummy are statistically significant at the $1 \%$ level, although somewhat smaller in magnitude $(-0.159$ and -0.24 in the two alternative specifications $) .{ }^{30}$

As the data does not record the exact terms that the defendants were offered in the plea bargaining process, we can only partially infer whether the reduced probability of accepting a plea bargain is due to the defendants being less willing to plead guilty holding the terms of the plea bargain constant or due to the prosecutors offering relatively worse terms. The SCPS data allows us to check one channel through which the prosecutors can make the bargains less generous, namely by being less likely to reduce the charge from felony to misdemeanor. ${ }^{31}$ Table 9 reports the estimates from a probit regression where the dependant variable equals one if the case was adjudicated as a misdemeanor (although all defendants in the dataset were initially arrested with a felony charge). The results show a significant reduction in the likelihood that the charges would be reduced to a misdemeanor (by 21.4 or 13.7\%, respectively, depending on the controls). The offense-specific effects (column 3) are roughly uniform across offense categories (and statistically significant at the $1 \%$ level for all crime categories except murder).

The findings that the prosecutors are less likely to reduce charges and the defendants are less likely to plead guilty are consistent with the "prosecutorial maximization" hypothesis of

\footnotetext{
${ }^{30}$ Detailed results are available upon request.

${ }^{31}$ Other channels include being less likely to drop some of the multiple charges, being less likely to charge with a less serious offense, or offering a higher sentence.
} 
Kessler and Piehl (1998) and are not consistent with the "furtherance of justice" view of the prosecutors - apparently the prosecutors did not offset the more severe punishment through more generous terms in plea bargaining since in that case we would unambiguously observe that the defendants became more likely to accept the plea.

\subsection{Length of sentence imposed upon conviction}

The last channel of the behavioral response operates through the maximum sentence imposed upon conviction. We run Tobit and quantile regressions on the subsample of cases in which the defendant was convicted. The dependant variable is the logarithm of the maximum prison or jail sentence imposed. The right-hand side variables are the same as in the regressions estimating the sentence conditional on arrest except that we add a dummy variable for whether the defendant pleaded guilty and an interaction of the plea dummy with the TIS case dummy. The plea dummy captures the difference between the sentence in plea and trial cases while its interaction with the TIS case dummy allows us to see whether the TIS laws had a differential impact on sentencing in plea cases vis-à-vis the trial cases. We also include a dummy variable equal to one when a state has sentencing guidelines and its interaction with the TIS case dummy. The official sentencing policies clearly differ between the states with and without sentencing guidelines and one should also expect the impacts of the TIS laws to be different in the guidelines states which put more restrictions on the judges' discretion.

The Tobit estimates are presented in Table 10. In the specifications without the sentencing guidelines controls (columns 1-2), the coefficients on the TIS case dummy are positive and significant at the $1 \%$ level (0.237 and 0.211). The coefficients on the plea-TIS interactions are negative -0.173 and -0.157 ) implying that the TIS laws increased maximum sentences 
in plea cases by about 16 percent less than in trial cases. The magnitude of these coefficients increases slightly when the sentencing guidelines controls are added to the regressions. The guidelines themselves have a significantly negative effect on the length of sentence (perhaps surprisingly the sentences are almost $30 \%$ shorter in the guidelines states). More interestingly, the interaction between the sentencing guidelines and the TIS dummy is negative and significant (between -0.119 and -0.134 ). Although the TIS laws had a positive effect on the maximum sentences overall, the effect is relatively weaker in the states with the sentencing guidelines.

These results contradict the hypothesis that the judges mitigate the higher fraction of the sentence served by imposing shorter sentences. ${ }^{32}$ One explanation is that our TIS case dummy is still partially correlated with other "tough on crime" policies even after controlling for the presence of the TIS law in the state, and the resulting upward bias is, at least in the length of sentence regressions, greater than the behavioral response. The coefficients on the sentencing guidelines-TIS interaction further support this explanation - the sentences rose by less in the guidelines states where the judges have less discretion to adjust sentences in either direction. The second explanation comes from a change in the sample composition which our current estimates do not correct for. As the cases covered by the TIS laws are more likely to be dismissed, the relatively weaker cases that would have received relatively shorter sentences drop out of the sample. Also, defendants covered by the TIS laws are more likely to reject the plea bargain and go to trial. All else equal (including a sentence received if pleading guilty), the marginal defendant who was indifferent between a guilty

\footnotetext{
${ }^{32}$ The only rather weak indicator of the offsetting behavior are the offense-specific effects of the TIS laws (column 7). For property and drug/other crimes, the coefficients are negative as expected, yet they have large standard errors.
} 
plea and a trial expects to receive a longer sentence at trial than an inframarginal defendant who strictly preferred going to trial. If an exogenous factor shifts the marginal defendant to choose to go to trial, the average sentence at trial would then rise, and the average sentence in plea bargains would fall.

\subsection{Robustness checks}

Our main results are generally robust to alternative specifications. Tables 11 and 12 report the basic OLS estimates of the expected imposed sentence conditional on arrest and the sentence imposed upon conviction. In the expected sentence regressions, the coefficients on the TIS dummy are about half the magnitude of our preferred Tobit estimates. In the sentence conditional on conviction regressions, the coefficients on the TIS dummies are also positive but smaller in magnitude (columns 1-2 and 4-5). The interaction between the TIS and plea dummies remains negative and significant while the interaction between the TIS and guidelines dummies remains also negative and is actually greater than in the Tobit specification.

The second set of checks exploits the variation in the intensity of the TIS laws. There are two sources of such variation. First, while most states followed the federal law and required offenders to serve 85 percent of the sentence, 3 states in our sample opted for 100 percent $^{33}$ and 2 states for $50 \%$ only. ${ }^{34}$ Second, the fraction of the time actually served had varied among states and offenses prior to the adoption of the TIS laws. We expect the TIS laws to "bite" more if the offenders had previously served a shorter fraction of the sentence. We ran

\footnotetext{
${ }^{33}$ Georgia, Pennsylvania, Virginia.

${ }^{34}$ Indiana, Maryland.
} 
the same set of regressions where we replaced the TIS dummy variable (and all interactions) with a continuous variable equal to the predicted fraction of the sentence served.

The predicted fraction is constructed as follows: For cases not covered by the TIS laws, it is computed from the National Corrections Reporting Program (NCRP) data series, individual level data on approximately 2.9 million prisoners released from prison between 1989 and $2002{ }^{35}$ The data were collected at the time of release and contain information on the individual characteristics of prisoners, the offense for which they were sentenced, the maximum and minimum sentence to which they were sentenced and the time served under the current admission. The predicted fraction of the sentence served is calculated by dividing the time served by the maximum sentence for each offender and then taking the average for each state-year-offense combination. The information about the time of admission to prison allows us to distinguish which prisoners were sentenced under the TIS laws and which were not. The number of observations for some states $^{36}$ is too small to allow predicting the fraction for each state-year-offense. These states were dropped, reducing the number of observations used in the regressions by $7 \%$. For cases covered by the TIS laws, we set the predicted fraction to the minimum fraction required by the TIS legislation in the respective state for the respective offense. ${ }^{37}$

\footnotetext{
${ }^{35}$ The data is available at http://www.icpsr.umich.edu/cocoon/ICPSR/SERIES/00038.xml.

${ }^{36}$ Arizona, Connecticut, District of Columbia, Indiana, Pennsylvania.

${ }^{37}$ Ideally, we would like to use the predicted fraction served for cases covered by the TIS laws as well. However, we have two reasons why we prefer the legislated rather than predicted fraction. First, the predicted fraction is likely to be downward-biased for the cases covered by the TIS laws. New admissions to prison covered by the TIS laws occur only after the TIS laws are in force (1994 or later in most states). The NCRP dataset therefore cannot record releases of prisoners who served 8 or more years post-TIS (and actually more than a mere 2 years for those admitted to prison in 2000). Missing observations for releases after 2002 induces a downward bias in the estimate of the fraction since we are more likely to observe prisoners who were released early. Due to this limitation we are also unable to observe post-TIS fraction of the sentence served for very long maximum sentences. Second, it may be more plausible to assume that agents in the criminal process acted upon the expectation that the post-TIS offenders would serve the legislated minimum fraction rather than the ex-post realizations of the fraction.
} 
The results are presented in Table $13 .{ }^{38}$ Consistent with the previous results, they show a statistically significant reduction in the probability of conviction both in the full sample of cases and for cases resolved at trial. Quantitatively, the coefficient of -0.178 in the probability of conviction regression implies approximately a 6 percent reduction in that probability, ${ }^{39}$ which is smaller than the coefficients on the TIS dummy in Table 3. On the other hand, the implied reduction in the probability of conviction conditional on trial is greater than in the specifications with the TIS dummy. Qualitatively and quantitatively similar estimates are obtained for the probability of reducing charges to a misdemeanor, and the expected sentence imposed. The effect on the probability of a guilty plea is negative but very small and statistically insignificant. For two outcomes the specification with the expected fraction implies qualitatively different results than the TIS dummy: the results imply a decrease instead of an increase in the probability that the case would be dismissed, and a statistically significant reduction in the maximum sentence imposed upon conviction. The last result is at least consistent with the theoretical prediction that judges should respond to the TIS laws by imposing shorter sentences, which was not confirmed in the main regressions (Table 10).

\section{Conclusions}

Our evaluation of the impacts of the Truth-in-Sentencing laws produced consistent evidence on several channels of behavioral responses to longer effective prison sentences in the criminal

\footnotetext{
${ }^{38}$ Due to space limitations, only the coefficients on the expected fraction served and their standard errors are reported, and the regressions estimating the TIS effects for individual offense categories are not reported. Full results are available upon request.

${ }^{39}$ The TIS laws raised the expected fraction of the sentence served from approximately $50 \%$ to $85 \%$, i.e., by approximately 0.35 . The coefficients on the fraction served should therefore be divided by $1 / 0.35$ (approximately 3 ) to obtain estimates comparable to those on the TIS dummy variable.
} 
justice process: First, longer sentences significantly reduced the probability that an arrested offender is convicted. This result represents one of the first empirical tests of the popular Andreoni (1991) model. Moreover, the magnitude of the reduction (about 25\%) is economically significant and suggests that this line of behavioral response should be seriously considered in the design of sentencing policies.

Second, the TIS laws induced prosecutors to make less advantageous offers in plea bargaining, to which the defendants responded by being less willing to plead guilty. Our results thus contradict several studies finding that the prosecutors instead tend to mitigate the direct effects of more severe sentences (Bjerk (2005), Walsh (2004)). Rather they support the view of prosecutors as agents who maximize the punishment imposed on the defendants and respond to more severe sentences by offering tougher terms in plea bargaining (Kessler and Piehl 1998). These contradicting results can hardly be attributed to the differences in empirical methodology, particularly as Bjerk (2005) adopts a very similar diff-in-diff-in-diff empirical strategy, uses the same data, but estimates the prosecutors' response to a different policy that enhanced sentences, namely the three-strikes laws. We instead hypothesize that the responses of prosecutors (and other enforcement agents) to enhanced legislated sentences are to some extent context-specific. One can think of prosecutors' behavior as being driven by a mixture of individual maximization and broader concern for justice. Which of the two forces prevails in their behavioral response to a legislative change then depends on whether the change conforms to the prosecutors' norms of justice. If the prosecutors regard more severe sentences as unjust, the tendency to "further justice" would dominate and their actions would mitigate the increased severity. On the other hand, if longer sentences in a given context do not contradict or even conform to the prosecutors' norm of justice, the desire 
to mitigate is absent and we observe responses consistent with narrow maximization objectives. The prosecutors apparently shared the objectives of the legislation (Shepherd 2002) which possibly explains why their observed responses are consistent with the prosecutorial maximization in the context of the TIS laws but not in other contexts.

Last, the overall effect of the TIS laws was a reduction in the imposed sentence expected upon arrest. The stated intention of the TIS laws to increase criminal punishment was therefore somewhat mitigated by the behavioral responses on several margins throughout the criminal procedure. In terms of magnitude, while the direct objective of the TIS laws to increase the fraction of the sentence served to $85 \%$ would have increased the expected actual sentence by $70 \%$ on average, the reduction of the expected imposed sentence by $14 \%$ implies that the expected actual sentence rose by "only" 56\%. The behavioral responses have therefore undone about one-fifth of the intended direct effect of the TIS laws. Also, they inevitably increased the disparities in punishment. Because of the TIS laws, a higher fraction of defendants walk away with no punishment at all while a smaller fraction of those who are convicted are punished much more severely. 


\section{References}

[1] Andreoni, J. (1991). Reasonable Doubt and the Optimal Magnitude of Fines: Should the Penalty Fit the Crime? The RAND Journal of Economics 22(3), 385-395.

[2] Bjerk, D. (2005). Making the Crime Fit the Penalty: The Role of Prosecutorial Discretion Under Mandatory Minimum Sentencing. Journal of Law and Economics 48, 591-625.

[3] Ditton P.M. and D.J.Wilson (1999). Truth in Sentencing in State Prisons, Bureau of Justice Statistics Special Report.

[4] Dharmapala, D., Garoupa N., and J.M.Shepherd (2006). Sentencing Guidelines, TIS Legislation, and Bargaining Power, unpublished manuscript, available at http://law.bepress.com/alea/16th/art35.

[5] Genego, W.J., P.D. Goldberger, and V.C. Jackson (1975). Parole Release Decisionmaking and the Sentencing Process. Yale Law Journal 84(4), 810-902.

[6] Kessler, D.P. and A.M. Piehl (1998). The Role of Discretion in the Criminal Justice System. Journal of Law, Economics and Organization 14(2), 256-276.

[7] Kuziemko, I. (2006). Does the Threat of the Death Penalty Affect Plea Bargaining in Murder Cases? Evidence from New York's 1995 Reinstatement of Capital Punishment. American Law and Economics Review 8(1),116-142.

[8] Landes, William M. (1971). The Economics Analysis of Courts. Journal of Law and Economics 14(1), 61-107.

[9] Reinganum, J.F. (1988). Plea Bargaining and Prosecutorial Discretion. The American Economic Review 78(4), 713-728.

[10] Reinganum, J.F. (2000). Sentencing Guidelines, Judicial Discretion, and Plea Bargaining. The RAND Journal of Economics 31(1), 62-81.

[11] Shepherd, J.M. (2002). Police, Prosecutors, Criminals, and Determinate Sentencing: The Truth about Truth-in-Sentencing Laws. Journal of Law and Economics 45, 509-534.

[12] Shepherd, J.M. (2006). Blakeley's Silver Lining: Sentencing Guidelines, Judicial Discretion, and Crime. Emory University School of Law, Law and Economics Research Paper No. 06-14.

[13] Snyder, E.A. (1990). The Effect of Higher Criminal Penalties on Antitrust Enforcement. Journal of Law and Economics 33(2), 439-462.

[14] U.S. Department of Justice, Office of the Attorney General (1993). Combating Violent Crime: Twenty-Four Recommendations to Strengthen Criminal Justice.

[15] U.S. Department of Justice, Office of Justice Programs (2005). Violent Offender Incarceration and Truth-in-Sentencing Incentive Formula Grant Program. Report to Congress.

[16] Walsh, J.E. (2004). Tough for Whom? How Prosecutors and Judges Use Their Discretion to Promote Justice under the California Three-Strikes Law. Crime and Justice Policy Program of the Henry Salvatori Center for the Study of Individual Freedom in the Modern World, Henry Salvatori Center Monograph New Series No. 4. 
Table 1: Adoption of the TIS laws

\begin{tabular}{l|ccl}
\hline \hline State & Year of Introduction & requirement(\%) & Type of crime covered \\
\hline Alabama & NA & & \\
Arizona & 1994 & 85 & all \\
California & 1994 & 85 & violent felony \\
Connecticut & 1996 & 85 & violent felony \\
District of Columbia & 1989 & 85 & violent felony \\
Florida & 1995 & 85 & all \\
Georgia & 1995 & 85 & violent felony \\
Hawaii & NA & & \\
Illinois & 1995 & 85 & all \\
Indiana & NA & & \\
Kentucky & 1998 & 85 & violent felony \\
Massachusetts & NA & & \\
Maryland & NA & & \\
Michigan & 1994 & 85 & part I violent \\
Missouri & 1994 & 85 & repeat or dangerous felony \\
New Jersey & 1997 & 85 & violent felony \\
New York & 1995 & 85 & violent felony \\
Ohio & 1996 & 85 & felony \\
Pennsylvania & 1911 & 100 & part I violent \\
Tennessee & 1995 & 85 & violent felony \\
Texas & 1993 & 50 & aggravated \\
Utah & 1985 & 85 & all \\
Virginia & 1995 & 100 & felony \\
Washington & 1990 & 85 & part I violent \\
Wisconsin & 1999 & felony \\
\hline Sour: & &
\end{tabular}

Sources:

United States General Accounting Office: Truth In Sentencing: Availability of Federal Funds s Influenced Law in Some States, Report to Congressional Requesters, Feb.1998.

Chen, Elsa: Impact of Three Strikes and Truth in Sentencing on the Volume and Composition of CorrectionalPopulations, Report Submitted to the National Institute of Justice, March 2000. Table includes only the states which are in the SCPS data set. 
Table 2: Summary Statistics

\begin{tabular}{l|cc|cc}
\hline \hline \multirow{2}{*}{ \% convicted at trial } & \multicolumn{2}{|c|}{ violent crime } & \multicolumn{2}{c}{ non-violent crime } \\
\cline { 2 - 5 } & TIS=0 & TIS $=1$ & TIS=0 & TIS $=1$ \\
\hline \multirow{5}{*}{$\%$ dismissed or acquitted } & 75.25 & 75.52 & 80.90 & 77.6 \\
\% pleaded guilty & $(43.20)$ & $(43.02)$ & $(39.32)$ & $(41.74)$ \\
& 36.96 & 37.18 & 20.48 & 29.72 \\
plea sentence (months) & $(48.27)$ & $(48.33)$ & $(40.36)$ & $(45.70)$ \\
trial sentence(months) & 56.42 & 54.81 & 70.93 & 63.90 \\
& $(49.59)$ & $(49.77)$ & $(45.41)$ & $(48.03)$ \\
no. of prior felony convictions & 32.44 & 27.78 & 13.29 & 11.41 \\
\% black & $(91.49)$ & $(92.50)$ & $(40.92)$ & $(52.53)$ \\
& 100.86 & 133.55 & 34.78 & 15.77 \\
\% Hispanic & $(256.87)$ & $(346.91)$ & $(131.98)$ & $(37.87)$ \\
& $(1.61)$ & .94 & 1.16 & 1.08 \\
\% women & 39.21 & 37.18 & $(1.95)$ & $(1.94)$ \\
& $(48.83)$ & $(48.33)$ & $(47.30$ & 34.17 \\
age & 19.86 & 23.85 & 22.48 & $(47.43)$ \\
& $(39.90)$ & $(42.62)$ & $(41.74)$ & $(42.29)$ \\
\# observations & 10.50 & 13.89 & 17.14 & 18.13 \\
\hline
\end{tabular}

Standard errors in parentheses.

Only states that eventually adopted the TIS laws are included in the summary statistics. There are additional states in the sample (Alabama, Indiana, Hawaii, Massachusetts, Maryland, Texas) that did not introduce TIS. Observations from these states are used in the regressions but are not used in the summary statistics in Table 1 in order to show a change in the variables after the introduction of TIS on a constant sample of states. 
Table 3: Probit Estimates, Probability of Conviction Conditional on Arrest (all cases)

\begin{tabular}{|c|c|c|c|c|c|c|}
\hline & 1 & 2 & 3 & 4 & 5 & 6 \\
\hline TIS case & $\begin{array}{c}-0.241 \\
(0.026)^{* * *}\end{array}$ & $\begin{array}{c}-0.233 \\
(0.026)^{* * *}\end{array}$ & & $\begin{array}{c}-0.272 \\
(0.029)^{* * *}\end{array}$ & $\begin{array}{c}-0.260 \\
(0.029)^{* * *}\end{array}$ & \\
\hline TISstate & $\begin{array}{c}0.109 \\
(0.029)^{* * *}\end{array}$ & & $\begin{array}{c}0.111 \\
(0.029)^{* * *}\end{array}$ & $\begin{array}{c}0.100 \\
(0.029)^{* * *}\end{array}$ & & $\begin{array}{c}0.108 \\
(0.029)^{* * *}\end{array}$ \\
\hline $\begin{array}{l}\text { TISstate } \\
\mathrm{x} \text { violent }\end{array}$ & & $\begin{array}{c}0.107 \\
(0.032)^{* * *}\end{array}$ & & & $\begin{array}{c}0.115 \\
(0.033)^{* * *}\end{array}$ & \\
\hline $\begin{array}{l}\text { TIS case } \\
\text { - murder }\end{array}$ & & & $\begin{array}{l}-0.078 \\
(0.127)\end{array}$ & & & $\begin{array}{c}-0.314 \\
(0.145)^{* *}\end{array}$ \\
\hline $\begin{array}{l}\text { TIS case } \\
\text { - violent }\end{array}$ & & & $\begin{array}{c}-0.183 \\
(0.032)^{* * *}\end{array}$ & & & $\begin{array}{c}-0.145 \\
(0.036)^{* * *}\end{array}$ \\
\hline $\begin{array}{l}\text { TIS case } \\
\text { - property }\end{array}$ & & & $\begin{array}{c}-0.351 \\
(0.033)^{* * *}\end{array}$ & & & $\begin{array}{c}-0.442 \\
(0.041)^{* * *}\end{array}$ \\
\hline $\begin{array}{l}\text { TIS case } \\
\text { - drug and other }\end{array}$ & & & $\begin{array}{c}-0.238 \\
(0.032)^{* * *}\end{array}$ & & & $\begin{array}{c}-0.346 \\
(0.037)^{* * *}\end{array}$ \\
\hline Guidelines x TIS & & & & $\begin{array}{c}0.093 \\
(0.032)^{* * *} \\
-0.150 \\
(0.049)^{* * *}\end{array}$ & $\begin{array}{c}0.062 \\
(0.030)^{* *}\end{array}$ & \\
\hline $\begin{array}{l}\text { Guidelines x TIS } \\
\text { - murder }\end{array}$ & & & & & & $\begin{array}{c}0.845 \\
(0.298)^{* * *}\end{array}$ \\
\hline $\begin{array}{l}\text { Guidelines x TIS } \\
\text { - violent }\end{array}$ & & & & & & $\begin{array}{l}-0.103 \\
(0.053)^{*}\end{array}$ \\
\hline $\begin{array}{l}\text { Guidelines x TIS } \\
\text { - drug and other }\end{array}$ & & & & & & $\begin{array}{c}0.242 \\
(0.052)^{* * *}\end{array}$ \\
\hline $\begin{array}{l}\text { Guidelines x TIS } \\
\text { - drug and other }\end{array}$ & & & & & & $\begin{array}{c}0.197 \\
(0.050)^{* * *}\end{array}$ \\
\hline $\begin{array}{l}\text { Guidelines } \\
\text { - murder }\end{array}$ & & & & & & $\begin{array}{c}-0.383 \\
(0.218)^{*}\end{array}$ \\
\hline $\begin{array}{l}\text { Guidelines } \\
\text { - violent }\end{array}$ & & & & & & $\begin{array}{c}-0.262 \\
(0.106)^{* * *}\end{array}$ \\
\hline $\begin{array}{l}\text { Guidelines } \\
\text { - property }\end{array}$ & & & & & & -0.283 \\
\hline $\begin{array}{l}\text { Guidelines } \\
\text { - drug and other }\end{array}$ & & & & & & $\begin{array}{c}0.020 \\
(0.059)\end{array}$ \\
\hline \# observations & 83506 & 83506 & 83506 & 83506 & 83506 & 83506 \\
\hline Pseudo $\mathrm{R}^{2}$ & 0.1509 & 0.1509 & 0.1512 & 0.1510 & 0.1510 & 0.1529 \\
\hline
\end{tabular}

Standard errors in parentheses

* significant at $10 \%$; ** significant at $5 \%$; *** significant at $1 \%$

The reported coefficients denote the marginal effects on the probability. All regressions include the individual characteristics of the offender and the case, offense dummies, year dummies, and county dummies interacted with a violent crime dummy (coefficients not shown due to space limitations). 
Table 4: Tobit Estimates, Imposed Sentence Conditional on Arrest (all cases)

\begin{tabular}{|c|c|c|c|c|c|c|}
\hline & 1 & 2 & 3 & 4 & 5 & 6 \\
\hline \multirow[t]{2}{*}{ TIS case } & -0.148 & -0.215 & & -0.099 & -0.144 & \\
\hline & $(0.052)^{* * *}$ & $(0.054)^{* * *}$ & & $(0.041)^{* *}$ & $(0.044)^{* * *}$ & \\
\hline \multirow[t]{2}{*}{ TISstate } & 0.163 & & 0.165 & 0.121 & & 0.123 \\
\hline & $(0.058)^{* * *}$ & & $(0.058)^{* * *}$ & $(0.045)^{* * *}$ & & $(0.045)^{* * *}$ \\
\hline TISstate & & 0.330 & & & 0.223 & \\
\hline $\mathrm{x}$ violent & & $(0.071)^{* * *}$ & & & $(0.057)^{* * *}$ & \\
\hline TIS case & & & 0.510 & & & 0.468 \\
\hline - murder & & & $(0.244)^{* *}$ & & & $(0.178)^{* * *}$ \\
\hline TIS case & & & 0.027 & & & 0.008 \\
\hline - violent & & & $(0.067)$ & & & $(0.052)$ \\
\hline TIS case & & & -0.321 & & & -0.205 \\
\hline - property & & & $(0.070)^{* * *}$ & & & $(0.057)^{* * *}$ \\
\hline TIS case & & & -0.267 & & & -0.195 \\
\hline - drug and other & & & $(0.065)^{* * *}$ & & & $(0.052)^{* * *}$ \\
\hline cut off - left & 0 & 0 & 0 & 1.7 & 1.7 & 1.7 \\
\hline cut off - right & 6.5 & 6.5 & 6.5 & 6.5 & 6.5 & 6.5 \\
\hline \# observations & 83244 & 83244 & 83244 & 83244 & 83244 & 83244 \\
\hline pseudo $\mathrm{R}^{2}$ & 0.0940 & 0.0941 & 0.0941 & 0.1150 & 0.1151 & 0.1151 \\
\hline
\end{tabular}

Standard errors in parentheses

* significant at $10 \%$; ** significant at $5 \%$; *** significant at $1 \%$

The dependant variable is the logarithm of the sentence imposed upon adjudication of the case, set as the length of the prison or jail sentence (in months) if the defendant was convicted and zero if he was not convicted. All regressions include the individual characteristics of the offender and the case, offense dummies, year dummies, and county dummies interactedwith a violent crime dummy (coefficients not shown due to space limitations). 
Table 5: Quantile Estimates, Imposed Sentence Conditional on Arrest (all cases)

\begin{tabular}{lcccc}
\hline \hline & 1 & 2 & 3 & 4 \\
\hline TIS case & -0.021 & -0.288 & 0.045 & -0.189 \\
& $(0.021)$ & $(0.049)^{* * *}$ & $(0.020)^{* *}$ & $(0.050)^{* * *}$ \\
TISstate & 0.445 & 0.403 & & \\
& $(0.023)^{* * *}$ & $(0.054)^{* * *}$ & & \\
TISstate x violent & & & 0.098 & 0.193 \\
& & & $(0.026)^{* * *}$ & $(0.064)^{* * *}$ \\
\hline quantile & $75 \%$ & $90 \%$ & $75 \%$ & $90 \%$ \\
\hline \# observations & 83244 & 83244 & 83244 & 83244 \\
pseudo R & 0.2054 & 0.1454 & 0.2047 & 0.1446 \\
\hline \hline
\end{tabular}

Standard errors in parentheses

* significant at $10 \% ; * *$ significant at $5 \%$; *** significant at $1 \%$

The dependant variable is the logarithm of the sentence imposed upon adjudication of the case, set as the length of the prison sentence (in months) if the defendant was convicted and zero if he was not convicted. All regressions include the individual characteristics of the offender and the case, offense dummies, year dummies, and county dummies interacted with a violent crime dummy (coefficients not shown due to space limitations). 
Table 6: Probit Estimates, Probablity of the Case Being Dismissed (all cases)

\begin{tabular}{lccc}
\hline \hline & 1 & 2 & 3 \\
\hline TIS case & 0.154 & 0.100 & \\
& $(0.027)^{* * *}$ & $(0.026)^{* * *}$ & \\
TISstate & -0.155 & & -0.156 \\
& $(0.031)^{* * *}$ & & $(0.031)^{* * *}$ \\
TISstate x violent & & -0.055 & \\
& & $(0.032)^{*}$ & \\
TIS case & & & 0.024 \\
- murder & & & $(0.131)$ \\
TIS case & & & 0.125 \\
- violent & & & $(0.033)^{* * *}$ \\
TIS case & & & 0.197 \\
- property & & & $(0.034)^{* * *}$ \\
TIS case & & & $(0.164$ \\
- drug and other & & & $833)^{* * *}$ \\
\hline \# observations & 83506 & 83506 & 83506 \\
pseudo R ${ }^{2}$ & 0.1270 & 0.1267 & 0.1270 \\
\hline \hline
\end{tabular}

Standard errors in parentheses

* significant at $10 \%$; ** significant at $5 \%$; ** significant at $1 \%$

The reported coefficients denote the marginal effects on the probability. All regressions include the individual characteristics of the offender and the case, offense dummies, year dummies, and county dummies interacted with a violent crime dummy (coefficients not shown due to space limitations). 
Table 7: Probit Estimates, Probability of Conviction (trial cases)

\begin{tabular}{|c|c|c|c|c|c|c|}
\hline & 1 & 2 & 3 & 4 & 5 & 6 \\
\hline TIS case & $\begin{array}{l}-0.237 \\
(0.148)\end{array}$ & $\begin{array}{l}-0.255 \\
(0.155)^{*}\end{array}$ & & $\begin{array}{c}0.054 \\
(0.179)\end{array}$ & $\begin{array}{c}0.095 \\
(0.203)\end{array}$ & \\
\hline TIS state & $\begin{array}{c}0.192 \\
(0.148)\end{array}$ & & $\begin{array}{c}0.2 \\
(0.148)\end{array}$ & $\begin{array}{c}0.216 \\
(0.149)\end{array}$ & & $\begin{array}{c}0.224 \\
(0.149)\end{array}$ \\
\hline $\begin{array}{l}\text { TISstate } \\
\text { x violent }\end{array}$ & & $\begin{array}{c}0.233 \\
(0.173)\end{array}$ & & & $\begin{array}{l}0.133 \\
(0.18)\end{array}$ & \\
\hline $\begin{array}{l}\text { TIS case } \\
\text { - murder }\end{array}$ & & & $\begin{array}{c}0.93 \\
(0.373)^{* *}\end{array}$ & & & $\begin{array}{c}0.848 \\
(0.416)^{* *}\end{array}$ \\
\hline $\begin{array}{l}\text { TIS case } \\
\text { - violent }\end{array}$ & & & $\begin{array}{l}-0.219 \\
(0.162)\end{array}$ & & & $\begin{array}{c}0.033 \\
(0.196)\end{array}$ \\
\hline $\begin{array}{l}\text { TIS case } \\
\text { - property }\end{array}$ & & & $\begin{array}{c}-0.606 \\
(0.207)^{* * *}\end{array}$ & & & $\begin{array}{c}-0.41 \\
(0.336)\end{array}$ \\
\hline $\begin{array}{l}\text { TIS case } \\
\text { - drug and other }\end{array}$ & & & $\begin{array}{c}-0.19 \\
(0.205)\end{array}$ & & & $\begin{array}{c}0.064 \\
(0.332)\end{array}$ \\
\hline Guidelines x TIS & & & & $\begin{array}{c}-0.533 \\
(0.171)^{* * *}\end{array}$ & $\begin{array}{c}-0.499 \\
(0.176)^{* * *}\end{array}$ & \\
\hline Guidelines & & & & $\begin{array}{c}0.58 \\
(0.263)^{* *}\end{array}$ & $\begin{array}{c}0.557 \\
(0.263)^{* *}\end{array}$ & \\
\hline $\begin{array}{l}\text { Guidelines x TIS } \\
\text { - violent }\end{array}$ & & & & & & $\begin{array}{c}-0.519 \\
(0.217)^{* *}\end{array}$ \\
\hline $\begin{array}{l}\text { Guidelines x TIS } \\
\text { - property }\end{array}$ & & & & & & $\begin{array}{l}-0.309 \\
(0.363)\end{array}$ \\
\hline $\begin{array}{l}\text { Guidelines x TIS } \\
\text { - drug and other }\end{array}$ & & & & & & $\begin{array}{l}-0.396 \\
(0.366)\end{array}$ \\
\hline $\begin{array}{l}\text { Guidelines } \\
\text { - murder }\end{array}$ & & & & & & $\begin{array}{c}1.058 \\
(0.600)^{*}\end{array}$ \\
\hline $\begin{array}{l}\text { Guidelines } \\
\text { - violent }\end{array}$ & & & & & & $\begin{array}{c}0.683 \\
(0.425)\end{array}$ \\
\hline $\begin{array}{l}\text { Guidelines } \\
\text { - property }\end{array}$ & & & & & & $\begin{array}{l}0.513 \\
(0.35)\end{array}$ \\
\hline $\begin{array}{l}\text { Guidelines } \\
\text { - drug and other }\end{array}$ & & & & & & $\begin{array}{c}0.45 \\
(0.345)\end{array}$ \\
\hline \# observations & 4417 & 4417 & 4417 & 4417 & 4417 & 4391 \\
\hline pseudo $\mathrm{R}^{2}$ & 0.1602 & 0.1602 & 0.1647 & 0.1629 & 0.1626 & 0.1658 \\
\hline
\end{tabular}

Standard errors in parentheses

* significant at $10 \%$; ** significant at $5 \%$; *** significant at $1 \%$

The reported coefficients denote the marginal effects on the probability. All regressions include the individual characteristics of the offender and the case, offense dummies, year dummies, and county dummies interacted with a violent crime dummy (coefficients not shown due to space limitations).

Interacted term of Guidelines, TIS case and the murder case is dropped due to collinearity 
Table 8: Probit Estimates, Probability of Pleading Guilty (all cases)

\begin{tabular}{|c|c|c|c|c|c|c|}
\hline & 1 & 2 & 3 & 4 & 5 & 6 \\
\hline TIS case & $\begin{array}{c}-0.254 \\
(0.026)^{* * *}\end{array}$ & $\begin{array}{c}-0.280 \\
(0.025)^{* * *}\end{array}$ & & $\begin{array}{c}-0.306 \\
(0.028)^{* * *}\end{array}$ & $\begin{array}{c}-0.352 \\
(0.029)^{* * *}\end{array}$ & \\
\hline TISstate & $\begin{array}{c}0.017 \\
(0.029)\end{array}$ & & $\begin{array}{c}0.017 \\
(0.029)\end{array}$ & $\begin{array}{l}-0.001 \\
(0.029)\end{array}$ & & $\begin{array}{c}0.004 \\
(0.029)\end{array}$ \\
\hline $\begin{array}{l}\text { TISstate } \\
\mathrm{x} \text { violent }\end{array}$ & & $\begin{array}{c}0.082 \\
(0.032)^{* *}\end{array}$ & & & $\begin{array}{c}0.096 \\
(0.032)^{* * *}\end{array}$ & \\
\hline $\begin{array}{l}\text { TIS case } \\
\text { - murder }\end{array}$ & & & $\begin{array}{c}-0.602 \\
(0.119)^{* * *}\end{array}$ & & & $\begin{array}{c}-0.802 \\
(0.139)^{* * *}\end{array}$ \\
\hline $\begin{array}{l}\text { TIS case } \\
\text { - violent }\end{array}$ & & & $\begin{array}{c}-0.197 \\
(0.032)^{* * *}\end{array}$ & & & $\begin{array}{c}-0.183 \\
(0.036)^{* * *}\end{array}$ \\
\hline $\begin{array}{l}\text { TIS case } \\
\text { - property }\end{array}$ & & & $\begin{array}{c}-0.351 \\
(0.033)^{* * *}\end{array}$ & & & $\begin{array}{c}-0.450 \\
(0.040)^{* * *}\end{array}$ \\
\hline $\begin{array}{l}\text { TIS case } \\
\text { - drug and other }\end{array}$ & & & $\begin{array}{c}-0.243 \\
(0.031)^{* * *}\end{array}$ & & & $\begin{array}{c}-0.374 \\
(0.037)^{* * *}\end{array}$ \\
\hline Guidelines x TIS & & & & $\begin{array}{c}0.162 \\
(0.032)^{* * *}\end{array}$ & $\begin{array}{c}0.174 \\
(0.033)^{* * *}\end{array}$ & \\
\hline Guidelines & & & & $\begin{array}{c}-0.291 \\
(0.049)^{* * *}\end{array}$ & $\begin{array}{c}-0.290 \\
(0.048)^{* * *}\end{array}$ & \\
\hline $\begin{array}{l}\text { Guidelines x TIS } \\
\text { - murder }\end{array}$ & & & & & & $\begin{array}{c}0.744 \\
(0.268)^{* * *}\end{array}$ \\
\hline $\begin{array}{c}\text { Guidelines x TIS } \\
\text { - violent }\end{array}$ & & & & & & $\begin{array}{l}-0.022 \\
(0.053)\end{array}$ \\
\hline Guidelines x TIS & & & & & & 0.269 \\
\hline - property & & & & & & $(0.052)^{* * *}$ \\
\hline Guidelines x TIS & & & & & & 0.280 \\
\hline - drug and other & & & & & & $(0.049)^{* * *}$ \\
\hline Guidelines & & & & & & -0.633 \\
\hline - murder & & & & & & $(0.209)^{* * *}$ \\
\hline Guidelines & & & & & & -0.422 \\
\hline - violent & & & & & & $(0.104)^{* * *}$ \\
\hline Guidelines & & & & & & -0.392 \\
\hline - property & & & & & & $(0.057)^{* * *}$ \\
\hline Guidelines & & & & & & -0.143 \\
\hline - drug and other & & & & & & $(0.058)^{* *}$ \\
\hline \# observations & 83506 & 83506 & 83506 & 83506 & 83506 & 83506 \\
\hline
\end{tabular}

Standard errors in parentheses

* significant at $10 \%$; ** significant at $5 \%$; *** significant at $1 \%$

The reported coefficients denote the marginal effects on the probability. All regressions include the individual characteristics of the offender and the case, offense dummies, year dummies,and county dummies interacted with a violent crime dummy (coefficients not shown due to space limitations). 
Table 9: Probit Estimates, Probablity of Reducing Charges to a Misdemeanor (all cases)

\begin{tabular}{lccc}
\hline \hline & 1 & 2 & 3 \\
\hline TIS case & -0.214 & -0.137 & \\
& $(0.032)^{* * *}$ & $(0.030)^{* * *}$ & \\
TISstate & 0.165 & & 0.165 \\
& $(0.037)^{* * *}$ & & $(0.037)^{* * *}$ \\
TISstate x violent & & 0.017 & \\
& & $(0.037)$ & \\
TIS case & & & -0.278 \\
- murder & & & $(0.268)$ \\
TIS case & & & -0.203 \\
- violent & & & $(0.039)^{* * *}$ \\
TIS case & & & -0.209 \\
- property & & & $-0.040)^{* * *}$ \\
TIS case & & & $(0.038)^{* * *}$ \\
- drug and other & & 83287 & 83287 \\
\hline \# observations & 83287 & 0.1899 & 0.1902 \\
pseudo R & 0.1902 & & \\
\hline \hline
\end{tabular}

Standard errors in parentheses

$*$ significant at $10 \%$; ** significant at $5 \%$; *** significant at $1 \%$

The reported coefficients denote the marginal effects on the probability. All regressions include the individual characteristics of the offender and the case, offense dummies, year dummies, and county dummies interacted with a violent crime dummy (coefficients not shown due to space limitations). 
Table 10: Tobit Estimates, Length of Maximum Sentence Imposed (convicted cases)

\begin{tabular}{|c|c|c|c|c|c|c|}
\hline & 1 & 2 & 3 & 4 & 5 & 6 \\
\hline TIS case & $\begin{array}{c}0.237 \\
(0.071)^{* * *}\end{array}$ & $\begin{array}{c}0.211 \\
(0.074)^{* * *}\end{array}$ & & $\begin{array}{c}0.313 \\
(0.075)^{* * *}\end{array}$ & $\begin{array}{c}0.292 \\
(0.079)^{* * *}\end{array}$ & \\
\hline TISstate & $\begin{array}{c}0.097 \\
(0.037)^{* * *}\end{array}$ & & $\begin{array}{c}0.099 \\
(0.037)^{* * *}\end{array}$ & $\begin{array}{c}0.069 \\
(0.037)^{*}\end{array}$ & & $\begin{array}{c}0.105 \\
(0.038)^{* * *}\end{array}$ \\
\hline $\begin{array}{l}\text { TISstate } \\
\mathrm{x} \text { violent }\end{array}$ & & $\begin{array}{c}0.130 \\
(0.053)^{* *}\end{array}$ & & & $\begin{array}{c}0.084 \\
(0.054)\end{array}$ & \\
\hline Plea & $\begin{array}{c}-0.499 \\
(0.032)^{* * *}\end{array}$ & $\begin{array}{c}-0.506 \\
(0.032)^{* * *}\end{array}$ & $\begin{array}{c}-0.507 \\
(0.032)^{* * *}\end{array}$ & $\begin{array}{c}-0.499 \\
(0.032)^{* * *}\end{array}$ & $\begin{array}{c}-0.504 \\
(0.032)^{* * *}\end{array}$ & $\begin{array}{c}-0.497 \\
(0.032)^{* * *}\end{array}$ \\
\hline Plea x TIS & $\begin{array}{c}-0.173 \\
(0.067)^{* * *}\end{array}$ & $\begin{array}{c}-0.157 \\
(0.067)^{* *}\end{array}$ & $\begin{array}{c}-0.151 \\
(0.068)^{* *}\end{array}$ & $\begin{array}{c}-0.183 \\
(0.067)^{* * *}\end{array}$ & $\begin{array}{c}-0.171 \\
(0.067)^{* *}\end{array}$ & \\
\hline $\begin{array}{l}\text { TIS case } \\
\text { - murder }\end{array}$ & & & $\begin{array}{c}0.354 \\
(0.187)^{*}\end{array}$ & & & $\begin{array}{c}0.292 \\
(0.255)\end{array}$ \\
\hline $\begin{array}{l}\text { TIS case } \\
\text { - violent }\end{array}$ & & & $\begin{array}{c}0.293 \\
(0.078)^{* * *}\end{array}$ & & & $\begin{array}{c}0.529 \\
(0.096)^{* * *}\end{array}$ \\
\hline $\begin{array}{l}\text { TIS case } \\
\text { - property }\end{array}$ & & & $\begin{array}{c}0.220 \\
(0.081)^{* * *}\end{array}$ & & & $\begin{array}{l}-0.277 \\
(0.177)\end{array}$ \\
\hline $\begin{array}{l}\text { TIS case } \\
\text { - drug and other }\end{array}$ & & & $\begin{array}{c}0.131 \\
(0.077)^{*}\end{array}$ & & & $\begin{array}{c}0.109 \\
(0.138)\end{array}$ \\
\hline $\begin{array}{l}\text { TIS case } \\
\text { - misdemeanor }\end{array}$ & & & $\begin{array}{c}0.312 \\
(0.112)^{* * *}\end{array}$ & & & $\begin{array}{l}-0.255 \\
(0.340)\end{array}$ \\
\hline Guidelines x TIS & & & & $\begin{array}{c}-0.134 \\
(0.052)^{* * *}\end{array}$ & $\begin{array}{l}-0.119 \\
(0.053)^{* *}\end{array}$ & \\
\hline Guidelines & & & & $\begin{array}{c}-0.279 \\
(0.070)^{* * *} \\
\end{array}$ & $\begin{array}{c}-0.296 \\
(0.069)^{* * *} \\
\end{array}$ & \\
\hline \# observations & 55954 & 55954 & 55739 & 55954 & 55954 & 55739 \\
\hline pseudo $\mathrm{R}^{2}$ & 0.1578 & 0.1578 & 0.1582 & 0.1584 & 0.1581 & 0.1581 \\
\hline
\end{tabular}

Standard errors in parentheses

* significant at $10 \% ;{ }^{* *}$ significant at $5 \% ; * * *$ significant at $1 \%$

The dependant variable is the logarithm of the sentence imposed upon conviction (months). All regressions include the individual characteristics of the offender and the case, offense dummies, year dummies, and county dummies interacted with a violent crime dummy. Regression in column 6 includes also offense-specific interactions of the TIS dummy with the Plea and Guidelines dummies. (Coefficients not shown due to space limitations). 
Table 11: OLS Estimates, Length of Maximum Sentence Imposed (convicted cases)

\begin{tabular}{|c|c|c|c|c|c|c|}
\hline & 1 & 2 & 3 & 4 & 5 & 6 \\
\hline \multirow[t]{2}{*}{ TIS case } & 0.174 & 0.150 & & 0.191 & 0.157 & \\
\hline & $(0.061)^{* * *}$ & $(0.063)^{* *}$ & & $(0.064)^{* * *}$ & $(0.067)^{* *}$ & \\
\hline \multirow[t]{2}{*}{ TISstate } & 0.092 & & 0.094 & 0.064 & & 0.085 \\
\hline & $(0.030)^{* * *}$ & & $(0.030)^{* * *}$ & $(0.031)^{* *}$ & & $(0.031)^{* * *}$ \\
\hline TISstate & & 0.131 & & & 0.114 & \\
\hline $\mathrm{x}$ violent & & $(0.046)^{* * *}$ & & & $(0.047)^{* *}$ & \\
\hline \multirow[t]{2}{*}{ Plea } & -0.420 & -0.426 & -0.428 & -0.424 & -0.430 & -0.427 \\
\hline & $(0.028)^{* * *}$ & $(0.028)^{* * *}$ & $(0.028)^{* * *}$ & $(0.028)^{* * *}$ & $(0.028)^{* * *}$ & $(0.028)^{* * *}$ \\
\hline \multirow[t]{2}{*}{ Plea x TIS } & -0.125 & -0.109 & -0.102 & -0.124 & -0.109 & \\
\hline & $(0.058)^{* *}$ & $(0.059)^{*}$ & $(0.059)^{*}$ & $(0.059)^{* *}$ & $(0.059)^{*}$ & \\
\hline \multirow{2}{*}{$\begin{array}{l}\text { TIS case } \\
\text { - murder }\end{array}$} & & & 0.295 & & & 0.226 \\
\hline & & & $(0.171)^{*}$ & & & $(0.230)$ \\
\hline TIS case & & & 0.236 & & & 0.490 \\
\hline - violent & & & $(0.069)^{* * *}$ & & & $(0.087)^{* * *}$ \\
\hline TIS case & & & 0.132 & & & -0.397 \\
\hline - property & & & $(0.069)^{*}$ & & & $(0.145)^{* * *}$ \\
\hline TIS case & & & 0.072 & & & 0.051 \\
\hline - drug and other & & & $(0.066)$ & & & $(0.117)$ \\
\hline TIS case & & & 0.285 & & & -0.303 \\
\hline - misdemeanor & & & $(0.080)^{* * *}$ & & & $(0.230)$ \\
\hline \multirow[t]{2}{*}{ Guidelines x TIS } & & & & -0.339 & -0.356 & \\
\hline & & & & $(0.055)^{* * *}$ & $(0.055)^{* * *}$ & \\
\hline \multirow[t]{2}{*}{ Guidelines } & & & & -0.008 & 0.011 & \\
\hline & & & & $(0.041)$ & $(0.042)$ & \\
\hline \# observations & 55954 & 55954 & 55739 & 55954 & 55954 & 55739 \\
\hline $\mathrm{R}^{2}$ & 0.34 & 0.34 & 0.34 & 0.34 & 0.34 & 0.34 \\
\hline
\end{tabular}

Standard errors in parentheses

* significant at $10 \%$; $* *$ significant at $5 \%$; *** significant at $1 \%$

The dependant variable is the logarithm of the sentence imposed upon conviction (months). All regressions include the individual characteristics of the offender and the case, offense dummies, year dummies, and county dummies interacted with a violent crime dummy. Regression in column 6 includes also offense-specific interactions of the TIS case dummy with the Pleasand Guidelines dummies. (Coefficients not shown due to space limitations). 
Table 12: OLS Estimates, Expected Imposed Sentence (all cases)

\begin{tabular}{lcccc}
\hline \hline & 1 & 2 & 3 & 4 \\
\hline TIS case & 0.003 & -0.040 & -0.046 & \\
TISstate & $(0.021)$ & $(0.025)$ & $(0.025)^{*}$ & \\
& & 0.092 & &
\end{tabular}

TIS state $\mathrm{x}$ violent

$$
(0.028)^{* * *}
$$

$(0.032)^{* * *}$

TIS case

- murder

$(0.125)^{* * *}$

TIS case

- violent

TIS case

- property

$(0.032)^{* * *}$

TIS case

- drug and other

\begin{tabular}{lcccc} 
\# observations & 83244 & 83244 & 83244 & 83244 \\
$\mathrm{R}^{2}$ & 0.23 & 0.23 & 0.23 & 0.23 \\
\hline \hline
\end{tabular}

Standard errors in parentheses

* significant at $10 \%$;* significant at $5 \%$; *** significant at $1 \%$

The dependant variable is the logarithm of the sentence imposed upon adjudication of the case, set as the length of the prison or jail sentence (in months) if the defendant was convicted and zero if he was not convicted. All regressions include the individual characteristics of the offender and the case, offense dummies, year dummies, and county dummies interacted with a violent crime dummy (coefficients not shown due to space limitations). 
Table 13: Estimates of the TIS Effect Using the Predicted Fraction of the Sentence Served

\begin{tabular}{lcccc}
\hline \multicolumn{1}{c}{ Dependant Variable } & Sample & Regression & \multicolumn{2}{c}{ Specification } \\
& & & TISstate & TISstate x violent \\
\hline Probability of conviction & all cases & probit & -0.178 & -0.17 \\
& & & $(0.070)^{* *}$ & $(0.005)^{* *}$ \\
Expected imposed & all cases & tobit & 0.002 & -0.034 \\
sentence & & & $(0.010)$ & $(0.104)$ \\
Expected imposed & all cases & quantile, 90 th & -0.735 & -0.444 \\
sentence & & & $(0.107)^{* * *}$ & $(0.053)^{* * *}$ \\
Probability of dismissal & all cases & probit & -0.064 & -0.132 \\
& & & $(0.060)$ & $(0.061)^{* *}$ \\
Probability of conviction & trial cases & probit & -0.735 & -0.485 \\
& & & $(0.411)^{*}$ & $(0.371)$ \\
Probability of a guilty plea & all cases & probit & -0.039 & -0.041 \\
& & & $(0.069)$ & $(0.072)$ \\
Probability of reducing & all cases & probit & -0.338 & -0.298 \\
charges & & & $(0.070)^{* * *}$ & $(0.078)^{* * *}$ \\
Maximum sentence & convicted cases & tobit & -0.195 & -0.226 \\
imposed & & & $(0.176)$ & $(0.178)$ \\
\hline \hline
\end{tabular}

Standard errors in parentheses

* significant at $10 \% ; * *$ significant at $5 \% ; * * *$ significant at $1 \%$

The table reports coefficients on the fraction of the expected sentence served in regressions that are equivalent to regressions in Tables 3 through 5 except that

the TIS case dummy is replaced with the fraction of the expected sentence served. Specification "TISstate" denotes regressions controlling for the presence of the TIS law in the state (equation 3). Specification "TIS state x violent" denotes regressions controlling for an interaction of the TIS state dummy and a violent crime dummy (equation 4).

All regressions include the individual characteristics of the offender and the case, offense dummies, year dummies, and county dummies interacted with a violent crime dummy (coefficients not shown due to space limitations). 
Individual researchers, as well as the on-line and printed versions of the CERGE-EI Working Papers (including their dissemination) were supported from the European Structural Fund (within the Operational Programme Prague Adaptability), the budget of the City of Prague, the Czech Republic's state budget and the following institutional grants:

- Center of Advanced Political Economy Research [Centrum pro pokročilá politickoekonomická studia], No. LC542, (2005-2009),

- Economic Aspects of EU and EMU Entry [Ekonomické aspekty vstupu do Evropské unie a Evropské měnové unie], No. AVOZ70850503, (2005-2010);

- Economic Impact of European Integration on the Czech Republic [Ekonomické dopady evropské integrace na ČR], No. MSM0021620846, (2005-2011);

Specific research support and/or other grants the researchers/publications benefited from are acknowledged at the beginning of the Paper.

(c) Fusako Tsuchimoto and Libor Dušek, 2009

All rights reserved. No part of this publication may be reproduced, stored in a retrieval system or transmitted in any form or by any means, electronic, mechanical or photocopying, recording, or otherwise without the prior permission of the publisher.

Published by

Charles University in Prague, Center for Economic Research and Graduate Education (CERGE) and

Economics Institute ASCR, v. v. i. (EI)

CERGE-El, Politických vězňů 7, 11121 Prague 1, tel.: +420 224005 153, Czech Republic.

Printed by CERGE-EI, Prague

Subscription: CERGE-EI homepage: http://www.cerge-ei.cz

Editors: Directors of CERGE and EI

Managing editors: Deputy Directors for Research of CERGE and EI

ISSN 1211-3298

ISBN 978-80-7343-205-8 (Univerzita Karlova. Centrum pro ekonomický výzkum

a doktorské studium)

ISBN 978-80-7344-194-4 (Národohospodářský ústav AV ČR, v. v. i.) 
CERGE-EI

P.O.BOX 882

Politických vězňů 7

11121 Praha 1

Czech Republic http://www.cerge-ei.cz 